\title{
Pergeseran Pusat Kegiatan Upacara Di Situs Megalitik Puncak Gunung Lawu
}

\section{Priyatno Hadi Sulistyarto}

Keywords: mountain, shift, changes, culture, tradition, megalithic

\section{How to Cite:}

Sulistyarto, P. H. (1999). Pergeseran Pusat Kegiatan Upacara Di Situs Megalitik Puncak Gunung Lawu. Berkala Arkeologi, 19(1), 89-106. https://doi.org/10.30883/jba.v19i1.795

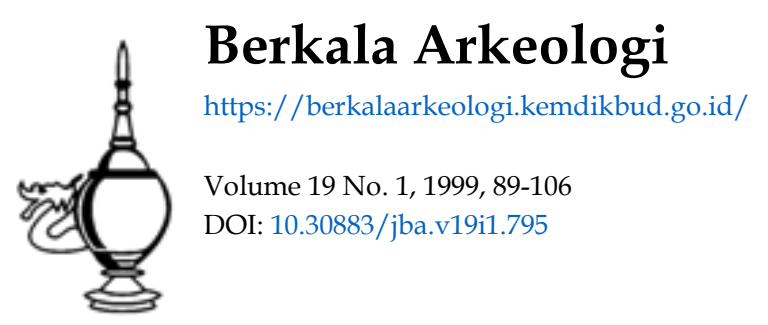

\section{(c) (7)(2)}

This work is licensed under a Creative Commons Attribution-NonCommercial-ShareAlike $\underline{4.0 \text { International License. }}$ 


\title{
PERGESERAN PUSAT KEGIATAN UPACARA \\ DI SITUS MEGALITIK PUNCAK GUNUNG LAWU
}

\author{
Priyatno Hadi Sulistyarto \\ (Balai Arkeologi Yogyakarta)
}

\section{A. Pendahuluan}

Situs Puncak Gunung Lawu belum lama dikenal di lingkungan para peneliti arkeologi, bahkan situs ini belum pernah disinggung-singgung sebagai peninggalan purbakala. Hal ini barangkali disebabkan oleh lokasi keberadaannya yang sangat sulit dijangkau. Padahal apabila dilihat dari potensi data arkeologi, situs ini memiliki kontribusi yang besar bagi studi megalitik di Indonesia.

Keberadaan tinggalan arkeologi di situs Gunung Lawu diketahui pertamakali berdasarkan laporan $F$. Junghun dalam majalah JAVA No. II tahun 1853. Laporan tersebut menguraikan bahwa tinggalan arkeologis di kawasan Gunung Lawu berupa bangunan berundak. Lokasi penemuannya berada di tiga tempat, yaitu di puncak Argo Tiling, Argo Blungkah, dan Argo Dumilah.

Tulisan lain yang menguraikan mengenai tinggalan arkeologis di kawasan Gunung Lawu terdapat pada buku terbitan Balai Pustaka pada tahun 1936 yang berjudul Tjarios Redi Lawoe. Buku karangan M. Hardjodisastro tersebut memuat tentang cerita-cerita rakyat yang berkaitan erat dengan tinggalan bangunan-bangunan batu di Puncak Gunung Lawu.

Kegiatan penelitian arkeologis di puncak Gunung Lawu pertamakali dilakukan oleh Himpunan Mahasiswa Arkeologi Universitas Gadjah Mada pada tahun 1986 dan 1987. Kegiatan penelitian pada tahun 1986 berupa survei yaitu bertujuan menguji kebenaran laporan F. Junghun. Dalam survei tersebut berhasil ditemukan delapan buah bangunan berundak dan beberapa temuan lepas lainnya. Survei pada tahun 1987 berhasil menemukan dua buah bangunan berundak yang lain, sehingga jumlah bangunan berundak secara keseluruhan sebanyak sepuluh buah. Selain itu diinformasikan bahwa bangunan-bangunan berundak tersebut merupakan unsur-unsur budaya megalitik yang sampai saat ini masih digunakan sebagai tempat pemujaan oleh masyarakat di sekitar Gunung Lawu (living megalithic monuments). Upacara pemujaan yang paling besar dilaksanakan pada malam menjelang tanggal 1 Suro (1 Muharram) (Marsis, 1987: 13). 


\section{B. Potensi Data Arkeologi Situs Puncak Gunung Lawu}

Lokasi situs Puncak Gunung Lawu berada di perbatasan antara wilayah administrasi Kecamatan Cemorosewu, Kabupaten Karanganyar, Propinsi Jawa Tengah dengan Kabupaten Magetan, Propinsi Jawa Timur. Secara astronomis situs puncak Gunung Lawu terletak antara $7^{\circ} 39^{\prime}$ LS dan $111^{\circ} 9^{\prime}$ BT Meredian Greenwich (Peta 1). Ukuran ketinggian puncak utama Gunung Lawu berdasarkan angka yang tertera pada titik triangulasi adalah $3.265 \mathrm{~m}$ di atas permukaan air laut. Suhu udara rata-rata $4^{\circ} \mathrm{C}$ dengan curah hujan rata-rata $3.912 \mathrm{~mm}$ pertahun. Lebih lanjut mengenai potensi arkeologis pada situs Puncak Gunung Lawu ini dapat diuraikan sebagai berikut.

\section{Bangunan Berundak Argo Dumilah}

Bangunan berundak Arga Dumilah terletak di puncak Arga Dumilah atau puncak utama Gunung Lawu. Lokasinya berada di sebelah utara kawah Lawu lama, dengan jarak sekitar $15 \mathrm{~m}$ dari bibir tebing kawah. Bangunan berundak Argo Dumilah dikelilingi talud dan pagar dari batu andesit bulat berdiameter antara 12 sampai $15 \mathrm{~cm}$ pada sisi utara, barat, dan timur, sedangkan pada sisi selatan menggunakan balok batu berukuran besar.

Bangunan ini memiliki tiga pintu pada sisi timur, utara, dan barat. Saat ini pintu yang masih digunakan secara intensif adalah pada sisi timur, sedangkan pada sisi utara dan barat tertutup oleh semak belukar. Pada sisi timur sepanjang $120 \mathrm{~m}$ dari pintu masuk terdapat tatanan batu dengan lebar $70 \mathrm{~cm}$ yang digunakan sebagai jalan. Pada bagian kanan dan kiri kedua ujung jalan terdapat 2 buah susunan batu berbentuk piramid dengan ukuran $170 \times 170 \times 90 \mathrm{~cm}$.

Bangunan ini berdenah persegi empat dengan ukuran, sisi timur $40,5 \mathrm{~m}$, sisi barat 45 $\mathrm{m}$, dan sisi utara kurang lebih $40 \mathrm{~m}$. Tiap-tiap sisinya terdapat pintu masuk kecuali pada sisi selatan karena berhadapan dengan kawah lawu. Bangunan berundak ini terdiri dari enam undakan, tiap-tiap undakan dibatasi dengan pagar dari bahan batuan andesit setinggi $1 \mathrm{~m}$ dan dihubungkan dengan pintu masuk dan tangga batu.

Bangunan berundak Argo Dumilah terdiri atas enam undakan dengan puncak undakan (undakan keenam) berbentuk persegi empat sama sisi dengan ukuran $9 \times 9 \mathrm{~m}$, sedangkan denah undakan pertama sampai kelima berbentuk U. Pintu masuk pada halaman undakan pertama terdapat susunan tangga batu setinggi $3,5 \mathrm{~m}$. Tangga batu pada halaman undakan kedua menuju undakan ketiga setinggi $3,5 \mathrm{~m}$. Pada halaman kedua terdapat lumpang batu dan prasasti. Lumpang batu tersebut berukuran $70 \times 50 \times$ $30 \mathrm{~cm}$, diameter lubang $25 \mathrm{~cm}$, dan kedalaman lubang $20 \mathrm{~cm}$. Dekat lumpang batu 
terdapat sebongkah batu yang pada salah satu permukaannya terdapat tatahan huruf Jawa Kuno yang menunjukkan angka 1360 Ç (Foto 1).

Halaman undakan ketiga dan keempat dihubungkan oleh pintu dengan ukuran lebar $70 \mathrm{~cm}$ dan tangga batu setinggi $4 \mathrm{~m}$. Halaman undakan keempat dan kelima juga dihubungkan dengan pintu dan tangga batu setinggi $2 \mathrm{~m}$. Sedangkan tangga batu pada halaman undakan kelima menuju halaman keenam setinggi $1,5 \mathrm{~m}$. Undakan keenam ini, pada bagian permukaan lantai dilapisi dengan tatanan batu andesit berbentuk persegi empat konsentris searah dengan keempat sisinya. Pada titik tengah halaman enam terdapat bangunan dari batu bata yang berfungsi sebagai titik triangulasi.

\section{Bangunan Berundak Argo Dumilah Timur}

Bangunan berundak Arga Dumilah Timur terletak di sebelah timur puncak Lawu dengan jarak sekitar $300 \mathrm{~m}$, berada pada punggung lereng dengan sudut kemiringan $34^{\circ}$. Bangunan ini berdenah persegi panjang dengan ukuran $44 \times 9,5 \mathrm{~m}$. Pada sisi timur terdapat pintu masuk menuju ke undakan pertama, selanjutnya berurutan hingga lantai teratas. Di depan pintu masuk halaman undakan pertama terdapat struktur jalan batu sepanjang $24 \mathrm{~m}$ menuju ke arah lembah sisi timur Gunung Lawu. Bangunan berundak ini terdiri dari lima undakan, tiap-tiap undakan dibatasi dengan pagar dari bahan batuan andesit setinggi $1 \mathrm{~m}$ dan dihubungkan dengan pintu masuk dan tangga batu. Bangunan ini berorientasi ke arah barat atau menuju ke arah bangunan berundak Argo Dumilah atau ke puncak utama Gunung Lawu.

Tangga batu di depan pintu masuk halaman undakan pertama berukuran tinggi $12 \mathrm{~m}$. Halaman undakan pertama berdenah persegi panjang dengan ukuran $20 \times 8 \mathrm{~m}$. Tiaptiap sisinya dibatasi dengan talud dari batu andesit setebal $1 \mathrm{~m}$. Jalan masuk menuju halaman undakan kedua berupa tangga batu setinggi $4 \mathrm{~m}$. Denah halaman undakan kedua berbentuk persegi panjang dengan ukuran $20 \times 8 \mathrm{~m}$. saat ini menunjukkan bahwa halaman undakan kedua bangunan ini digunakan sebagai jalur jalan menuju sisi selatan puncak Lawu, sehingga talud pada sisi utara dan selatan telah rusak.

Halaman undakan kedua dan ketiga dibatasi oleh pagar batu setinggi $1 \mathrm{~m}$. Kedua bagian ruang tersebut dihubungkan dengan pintu dan tangga batu setinggi $3 \mathrm{~m}$. Di sebelah selatan anak tangga terdapat sebuah lumpang batu berukuran $60 \times 60 \times 35 \mathrm{~cm}$, dengan diameter berukuran $29 \mathrm{~cm}$ dan kedalaman lubang $19 \mathrm{~cm}$. Denah halaman undakan ketiga berbentuk trapesium dengan ukuran sisi timur $20 \mathrm{~m}$, sisi utara dan selatan $8 \mathrm{~m}$, dan sisi barat $14 \mathrm{~m}$. Pada undakan ini ditemukan dua buah gundukan berukuran $7 \times 10 \times 0.4 \mathrm{~m}$ yang terdapat pada bagian utara dan selatan. Halaman undakan keempat berdenah empat persegi dengan ukuran $14 \times 8 \mathrm{~m}$. Di halaman ini juga ditemukan dua buah fitur gundukan tanah setinggi $30 \mathrm{~cm}$. Tangga batu menuju 
undakan kelima setinggi $1 \mathrm{~m}$, dibatasi oleh pagar batu andesit setinggi $1 \mathrm{~m}$ dan tebal 1 m. Halaman undakan kelima merupakan undakan paling atas pada bangunan ini. Denah halaman ini berbentuk empat persegi dengan ukuran $12 \times 8 \mathrm{~m}$. Temuan permukaan pada halaman ini berupa empat buah susunan batu berbentuk piramida dalam berbagai ukuran. Ukuran paling besar yaitu $3 \times 3 \times 2 \mathrm{~m}$. Sedangkan tiga piramida yang lain berukuran $1.1 \times 1.1 \times 1 \mathrm{~m}, 1 \times 1 \times 1 \mathrm{~m}$, dan $1 \times 1 \times 0,9 \mathrm{~m}$. Keempat piramida tersebut disusun berjajar dari arah selatan ke utara. Permukaan tanah di sebelah timur piramida tersebut ditinggikan $40 \mathrm{~cm}$ dengan ukuran panjang $2,5 \times 2,5 \mathrm{~m}$. Di sekitar piramida banyak ditemukan fragmen gerabah, bunga, dan sisa lilin.

\section{Bangunan berundak Argo Dumilah Utara}

Bangunan berundak Argo Dumilah Utara terletak di sebelah utara puncak utama Gunung Lawu pada jarak $200 \mathrm{~m}$. Denah bangunan ini berbentuk persegi panjang dengan ukuran sisi panjang kurang lebih 25 meter dan sisi lebar 9,5 meter. Kondisi bangunan pada saat ini sangat sulit diamati karena tertutup oleh semak belukar dan pepohonan. Pada sisi utara terdapat pintu masuk menuju ke undakan pertama. Di depan pintu masuk terdapat struktur jalan batu sepanjang $150 \mathrm{~m}$. Bangunan berundak ini terdiri dari lima undakan, tiap-tiap undakan dibatasi dengan pagar dari bahan batuan andesit setinggi satu meter dan dihubungkan dengan pintu masuk dan tangga batu di tengah. Bangunan ini berorientasi ke arah selatan atau menuju ke arah bangunan berundak Argo Dumilah atau ke puncak utama Gunung Lawu. Tiap-tiap undakan menunjukkan perbedaan ketinggian dengan beda tinggi antara 1-2 meter (Gambar 6). Pada halaman undakan teratas terdapat beberapa temuan permukaan berupa susunan batu andesit berbentuk meja berukuran $1,9 \times 1.6 \mathrm{~m}$, tinggi $1 \mathrm{~m}$.

\section{Bangunan berundak Argo Dumilah Barat}

Lokasi bangunan ini berada di sebelah barat bangunan berundak Argo Dumilah atau ke arah puncak utama Gunung Lawu. Bangunan ini berdenah persegi panjang dengan ukuran sisi panjang kurang lebih 23 meter dan sisi lebar 11,5 meter. Pada sisi barat terdapat pintu masuk menuju ke undakan pertama. Bangunan berundak ini terdiri dari tiga undakan, tiap-tiap undakan dibatasi dengan pagar dari bahan batuan andesit setinggi satu meter dan dihubungkan dengan pintu masuk dan tangga batu. Bangunan ini berorientasi ke arah timur atau menuju ke arah bangunan berundak Argo Dumilah. Tiap-tiap undakan menunjukkan perbedaan ketinggian dengan beda tinggi antara 1-2 meter, sehingga tinggi keseluruhan bangunan kurang lebih 5 meter. 
Halaman undakan pertama berukuran $11.5 \times 7 \mathrm{~m}$, temuan permukaan berupa lumpang batu dengan ukuran $30 \times 25 \times 23 \mathrm{~cm}$, diameter lubang $24 \mathrm{~cm}$, kedalaman $16 \mathrm{~cm}$. Halaman undakan kedua berukuran $11.5 \times 9 \mathrm{~m}$, Halaman undakan ketiga berukuran lebih kecil, yaitu $7 \times 8 \mathrm{~m}$. Halaman undakan ketiga dibagi menjadi dua ruang yang disekat dengan pagar batu setinggi $1 \mathrm{~m}$.

\section{Bangunan berundak Argo Dalem Barat}

Lokasi bangunan ini berada di sebelah timur laut bangunan berundak Argo Dumilah utara. Bangunan ini berdenah persegi panjang dengan ukuran sisi panjang kurang lebih $51.5 \mathrm{~m}$ dan sisi lebar $11,5 \mathrm{~m}$. Pada sisi timurlaut terdapat pintu masuk menuju ke undakan pertama. Struktur jalan batu yang berada di depan pintu utama sepanjang 142 $\mathrm{m}$ menuju ke lembah di sebelah utara yang disebut lembah Selo Pundutan. Di depan pintu utama terdapat empat pasang susunan batu yang berbentuk piramid yang berada dikanan-kiri jalan batu. Sepasang piramid pertama berada pada jarak $142 \mathrm{~m}$ dari pintu utama. Sepasang piramid kedua ditemukan di kanan-kiri jalan batu pada jarak $97 \mathrm{~m}$ dari pintu utama. Sepasang piramid ketiga ditemukan di kanan-kiri jalan batu pada jarak $40 \mathrm{~m}$ dari pintu utama. Sedangkan Sepasang piramid keempat ditemukan pada jarak $4 \mathrm{~m}$ dari pintu utama. Piramid tersebut berukuran $3.3 \times 2.5 \times 1.65 \mathrm{~m}$.

Bangunan berundak ini terdiri dari lima undakan, tiap-tiap undakan dibatasi dengan pagar dari bahan batuan andesit setinggi satu meter dan dihubungkan dengan pintu masuk dan tangga batu. Halaman undakan pertama berupa dataran tanah lapang tanpa pagar dengan ukuran luas $11,5 \times 65,5 \mathrm{~m}$. Lantai halaman ini lebih tinggi $2 \mathrm{~m}$ dari permukaan tanah di luar kompleks bangunan yang dibatasi oleh talud batu andesit. Jalan untuk memasuki halaman ini berupa tiga buah tangga batu yang berada di sisi timur, utara, dan barat.

Denah undakan kedua berbentuk empat persegi dengan ukuran $16,8 \times 4,9 \mathrm{~m}$. Jalan masuk berupa susunan anak tangga yang meninggi $3 \mathrm{~m}$, lebar $50 \mathrm{~m}$. Pagar batu halaman kedua ini berukuran tinggi $2 \mathrm{~m}$, tebal $2,5 \mathrm{~m}$. Undakan ketiga berdenah empat persegi dengan ukuran $16,5 \times 8 \mathrm{~m}$. Temuan permukaan pada halaman ini berupa lumpang batu yang terletak di samping pintu masuk. Ukuran lumpang batu $50 \times 50 \mathrm{x}$ $30 \mathrm{~cm}$. Diameter dan kedalaman lubang berukuran $25 \mathrm{~cm}$ dan $19 \mathrm{~cm}$. Selain itu terdapat fitur berupa permukaan tanah yang ditinggikan dengan ukuran $4 \times 6 \mathrm{~m}$, tinggi $40 \mathrm{~cm}$. Undakan keempat berdenah empat persegi dengan ukuran $13,2 \times 7.2 \mathrm{~m}$, pembatas berupa pagar setinggi $3 \mathrm{~m}$, jalan masuk berupa tangga batu setinggi $1 \mathrm{~m}$. Temuan permukaan berupa fitur permukaan tanah yang ditinggikan $40 \mathrm{~cm}$.

Undakan teratas atau kelima berdenah empat persegi dengan ukuran $11,6 \times 6 \mathrm{~m}$. Di halaman ini terdapat temuan permukaan yang berupa batu tegak dan lapik batuan 
andesit. Pada lapik tersebut terdapat tulisan dengan huruf Jawa Baru. Tulisan tersebut dapat dibaca sebagai Ki Ageng Honggoyudo. Bangunan ini berorientasi ke arah baratdaya atau menuju ke arah bangunan berundak Argo Dumilah atau ke puncak utama Gunung Lawu.

\section{Bangunan berundak Argo Dalem Barat Laut}

Lokasi bangunan ini berada di sebelah barat laut bangunan berundak Argo Dumilah. Bangunan ini berdenah persegi panjang dengan ukuran sisi panjang kurang lebih 19 meter dan sisi lebar 9,5 meter. Pada sisi baratlaut terdapat pintu masuk menuju ke undakan pertama. Bangunan berundak ini terdiri dari lima undakan, tiap-tiap undakan dibatasi dengan pagar dari bahan batuan andesit setinggi satu meter dan dihubungkan dengan pintu masuk dan tangga batu. Bangunan ini berorientasi ke arah tenggara atau menuju ke arah bangunan berundak Argo Dumilah. Tiap-tiap undakan menunjukkan perbedaan ketinggian dengan beda tinggi antara 1-2 meter, sehingga tinggi keseluruhan bangunan kurang lebih 11 meter .

\section{Bangunan berundak Argo Dalem Selatan}

Lokasi bangunan ini berada di sebelah timurlaut bangunan berundak Argo Dumilah Bangunan ini berdenah persegi panjang dengan ukuran sisi panjang kurang lebih 21 meter dan sisi lebar 14 meter. Pada sisi timurlaut terdapat pintu masuk menuju ke undakan pertama. Bangunan berundak ini terdiri dari dua undakan, tiap-tiap undakan dibatasi dengan pagar dari bahan batuan andesit setinggi satu meter dan dihubungkan dengan pintu masuk dan tangga batu. Bangunan ini berorientasi ke arah baratdaya atau menuju ke arah bangunan berundak Argo Dumilah. Undakan pertama berdenah empat persegi dengan ukuran $9 \times 4 \mathrm{~m}$. Undakan kedua berukuran $12 \times 10 \mathrm{~m}$.

\section{Bangunan berundak Argo Dalem Timur}

Lokasi bangunan ini berada di sebelah timurlaut puncak utama Gunung Lawu pada jarak $300 \mathrm{~m}$. Pada sisi timurlaut terdapat pintu masuk menuju ke undakan pertama. Bangunan berundak ini terdiri dari tujuh undakan, tiap-tiap undakan dibatasi dengan pagar dari bahan batuan andesit setinggi $3 \mathrm{~m}$ dan dihubungkan dengan pintu masuk dan tangga batu. Bangunan ini berorientasi ke arah baratdaya atau menuju ke arah bangunan berundak Argo Dumilah. Denah bangunan persegi empat melengkung mengikuti alur lereng timur puncak Gunung Lawu. 
Undakan pertama berdenah empat persegi menyerupai huruf $L$, dengan ukuran sisi utara $73,3 \mathrm{~m}$, lebar sisi barat $14,5 \mathrm{~m}$, dan sisi timur $23 \mathrm{~m}$. Jalan masuk dari arah timurlaut berbentuk susunan anak tangga batu setinggi $1,5 \mathrm{~m}$. Untuk memasuki undakan kedua melalui pintu dan tangga batu setinggi $3 \mathrm{~m}$, lebar $80 \mathrm{~cm}$. Undakan kedua berdenah empat persegi dengan ukuran $49 \times 10.7 \mathrm{~m}$.

Halaman undakan ketiga berdenah empat persegi yang dibagi menjadi dua ruangan dengan pembatas pagar batu setinggi $3 \mathrm{~m}$. Ruang sisi barat berukuran 24 x 10,8 m, sedangkan sisi timur berukuran 5,4 x 10,8 m, kedua ruangan itu dihubungkan oleh pintu selebar $1 \mathrm{~m}$. Pada ruangan sisi timur ditemukan lumpang batu dengan ukuran 70 x $60 \mathrm{~cm}$, diameter dan kedalaman berukuran $20 \mathrm{~cm}, 20 \mathrm{~cm}$. Halaman undakan keempat berdenah empat persegi, berukuran $14,8 \times 6,5 \mathrm{~m}$, dibatasi oleh pagar batu setinggi $1,5 \mathrm{~m}$. Di permukaan tanah terdapat batu-batu berserakan dari pagar yang telah roboh.

Halaman undakan kelima berdenah empat persegi, berukuran $13,2 \times 7,7 \mathrm{~m}$, dibatasi oleh pagar batu setinggi $2 \mathrm{~m}$. Tangga batu setinggi $1,5 \mathrm{~m}$, lebar $1 \mathrm{~m}$. Di halaman ini didirikan dua buah bangunan semi permanen oleh para pertapa, ukuran masingmasing $5 \times 4 \mathrm{~m}$. Halaman keenam berdenah empat persegi, berukuran $11,3 \times 6.4 \mathrm{~m}$. Pagar keliling dari batu andesit setinggi $2 \mathrm{~m}$. Penyekat dengan halaman ketujuh berupa pagar batu setinggi $50 \mathrm{~cm}$ dan dihubungkan dengan pintu dan tangga batu setinggi $2 \mathrm{~m}$, lebar $50 \mathrm{~cm}$.

Halaman teratas atau ketujuh berdenah empat persegi, berukuran $6,75 \times 4,6 \mathrm{~m}$. Pagar keliling setinggi $2,5 \mathrm{~m}$. Di halaman ini telah dibangun sebuah cungkup beratap joglo berukuran $3,4 \times 2,6 \mathrm{~m}$, tinggi $3 \mathrm{~m}$. Cungkup ini berlantai keramik warna putih, di dalamnya terdapat hiasan gunungan dan dua buah kalpataru dengan warna merahdan kuning menyala. Bangunan ini berfungsi sebagai pusat upacara pemujaan masa kini (Foto 2).

\section{Bangunan berundak Sendang Drajat}

Bangunan ini berdekatan dengan sumber mata air yang bernama Sendang Drajat, sehingga disebut bangunan berundak Sendang Drajat. Lokasinya berada di sebelah tenggara bangunan berundak Argo Dumilah. Bangunan ini berdenah persegi panjang dengan ukuran sisi panjang kurang lebih $19 \mathrm{~m}$ dan sisi lebar $9,5 \mathrm{~m}$. Pada sisi tenggara terdapat pintu masuk menuju ke undakan pertama. Bangunan berundak ini terdiri dari lima undakan, tiap-tiap undakan dibatasi dengan pagar dari bahan batuan setinggi satu meter dan dihubungkan dengan pintu masuk dan tangga batu. Bangunan ini berorientasi ke arah baratlaut atau menuju ke arah bangunan berundak Argo Dumilah. 
Tiap-tiap undakan menunjukkan perbedaan ketinggian dengan beda tinggi antara 1-2 meter, sehingga tinggi keseluruhan bangunan kurang lebih $9 \mathrm{~m}$.

\section{Bangunan berundak Pasar Dieng}

Keletakan bangunan berundak Pasar Dieng terpisah jauh dari bangunan-bangunan yang lain. Jarak untuk menuju ke bangunan ini sekitar 1.000 meter dari kompleks bangunan berundak Argo Dumilah. Lokasi kedua tempat tersebut terpisah oleh lembah. Bangunan berundak Pasar Dieng terletak di lereng puncak Argo Tiling, suatu puncak yang ketinggiannya nomor dua lebih rendah dari Argo Dumilah.

Bangunan ini berdenah persegi panjang dengan ukuran sisi panjang kurang lebih 19 meter dan sisi lebar 9,5 meter. Pada sisi tenggara terdapat pintu masuk menuju ke undakan pertama. Bangunan berundak ini terdiri dari tujuh undakan, tiap-tiap undakan dibatasi dengan pagar dari bahan batuan andesit setinggi satu meter dan dihubungkan dengan pintu masuk dan tangga batu. Bangunan ini berorientasi ke arah barat laut atau menuju ke arah puncak Argo Tiling. Tiap-tiap undakan menunjukkan perbedaan ketinggian dengan beda tinggi antara 1-2 meter, sehingga tinggi keseluruhan bangunan kurang lebih 8,5 meter.

\section{ANALISIS}

\section{Bangunan Berundak}

Bangunan berundak adalah suatu unsur budaya megalitik yang diwujudkan dalam suatu bangunan bertingkat atau berundak-undak, yang digunakan sebagai tempat pemujaan. Pada etnik Jawa bangunan berundak seringkali disebut dengan istilah lokal punden berundak. Punden berasal dari kata pundian yang berarti pujaan.

Pendirian bangunan berundak dapat dilakukan dengan dua cara, yaitu secara artifisial menimbun tanah untuk membentuk undak-undakan, atau dengan cara memanfaatkan fitur alam yang berupa morfologi perbukitan. Pada tiap-tiap batas undakan biasanya dibangun talud dan pagar dari batu yang selain berfungsi sebagai konstruksi penguat juga sebagai penegas batas undakan. Bangunan berundak di puncak Gunung Lawu didirikan dengan cara menggabungkan dua cara tersebut di atas, yaitu di samping mernanfaatkan perbukitan juga dilengkapi talud dan pagar keliling.

Ukuran luas bangunan berundak di situs puncak Gunung Lawu rata-rata $300-500 \mathrm{~m}^{2}$, kecuali satu bangunan inti yaitu bangunan berundak Argo Dumilah berukuran kurang lebih $1.000 \mathrm{~m}^{2}$. Data ini dapat menunjukkan bahwa bangunan-bangunan tersebut 
memiliki daya tampung dalam kapasitas yang besar. Selain itu, ditunjang oleh jumlah bangunan --yang sampai saat ini telah ditemukan sejumlah sepuluh buah-- merupakan petunjuk bahwa bangunan-bangunan tersebut sebagai prasarana bagi suatu kegiatan yang dilakukan oleh suatu komunitas manusia, dalam jumlah yang besar.

Suatu hal yang menarik perhatian adalah lokasi keletakan dan arah orientasi bangunan berundak di puncak Gunung Lawu menunjukkan pola memusat. Bangunan berundak Argo Dumilah yang terletak di puncak utama Gunung Lawu di kelilingi oleh delapan buah bangunan berundak lainnya yang berorientasi mengarah ke puncak. Pola keletakan memusat tersebut dapat diasumsikan bahwa ada pembagian fungsi bangunan, yaitu bangunan pusat dan bangunan bukan pusat. Hal ini barangkali berhubungan pula dengan jenis kegiatan yang dilakukan manusia pada bangunan tersebut, dimana bangunan pusat memiliki fungsi utama sedangkan bangunan bukan pusat berlaku sebagai pelengkap.

Di antara bangunan-bangunan berundak di situs puncak Gunung Lawu, terdapat satu bangunan yang menunjukkan arah orientasi yang berbeda dengan bangunan lain, yaitu bangunan berundak Pasar Dieng. Lokasi keletakan bangunan tersebut juga terpisah jauh dari bangunan-bangunan yang lain. Bangunan berundak Pasar Dieng berorientasi ke arah puncak Argo Tiling, suatu puncak yang ketinggiannya nomor dua lebih rendah dari Argo Dumilah. Fakta ini merupakan suatu gejala yang menarik, bahwa di antara sepuluh buah bangunan terdapat satu buah bangunan yang keletakannya tidak membentuk pola yang sama dengan bangunan-bangunan lainnya. Hal ini barangkali merupakan petunjuk bahwa di puncak Argo Tiling terdapat pula kompleks bangunan dengan pola keletakan yang sama dengan di puncak Argo Dumilah. Asumsi ini tentu saja memerlukan penelitian lanjutan untuk pembuktiannya.

\section{Batu tegak}

Batu tegak adalah salah satu bangunan megalitik yang berupa bongkahan batu yang memiliki ukuran tertentu dan biasanya berbentuk silindrik. Cara pendirian bangunan ini dilakukan dengan menanam salah satu bagian ujung batu ke dalam tanah dengan posisi tegak/vertikal, sehingga salah satu ujung batu yang lain menjulang ke atas.

Batu tegak sering disebut dengan istilah menhir. Tinggalan megalitik yang berupa menhir dalam masyarakat prasejarah merupakan perwujudan dari arwah nenek moyang, sehingga dalam suatu upacara pemujaan benda ini berfungsi sebagai media persembahan. Pada umumnya selain berfungsi sakral, menhir juga memiliki fungsi profan, yaitu sebagai tanda batas wilayah, dan pintu masuk (Simanjuntak, 1992:20). 
Menhir di situs puncak Gunung Lawu terletak di undakan paling atas, suatu area yang berfungsi sebagai pusat aktifitas upacara. Berdasarkan lokasi keletakan tersebut sangat dimungkinkan bahwa menhir pada bangunan berundak di situs puncak Gunung Lawu memiliki fungsi sakral yaitu sebagai media pemujaan terhadap arwah nenek moyang.

\section{Lumpang batu}

Lumpang batu pada dasarnya merupakan suatu bongkahan batu atau juga dari bahan lainnya yang memiliki suatu lubang sebagai ciri utama. Benda ini berfungsi praktis sebagai alat untuk wadah menumbuk padi atau biji-bijian lainnya. Lumpang batu merupakan komponen penting dalam masyarakat agraris.

Dalam konteks megalitik benda ini memiliki fungsi religius. Dalam suatu upacara pemujaan lumpang batu berfungsi sebagai simbol dari suatu pengharapan akan kesuburan bagi hasil pertanian. Selain itu lumpang batu juga merupakan simbol adanya hubungan antara arwah nenek moyang dengan kesejahteraan manusia yang masih hidup di dunia (Simanjuntak, 1992:20).

Berdasarkan uraian di atas maka keberadaan lumpang batu pada bangunan berundak di situs puncak Gunung Lawu cenderung berkaitan dengan fungsi religius. Benda ini dapat diartikan sebagai simbol pengharapan akan kesejahteraan hidup bagi pelaku pemujaan pada bangunan berundak di situs Puncak Gunung Lawu.

\section{Prasasti}

Prasasti yang ditemukan di situs puncak Gunung Lawu terbuat dari bahan batuan andesit, ditemukan di undakan ketiga bangunan berundak Argo Dumilah. Wujud dari benda ini berupa bongkahan batu yang sama sekali tidak dikerjakan, sehingga tulisan yang ada dalam prasasti tersebut ditatahkan pada permukaan batu yang relatif rata. Prasasti tersebut telah berhasil dibaca oleh para ahli epigrafi Indonesia, yaitu Soekarto Karto Atmodjo, Kusen, dan Budi Susanto. Menurut hasil pembacaan yang dilakukan pada tahun 1993 inskripsi pada prasasti itu berhuruf Jawa Kuno yang berupa angka tahun $1360 \mathrm{C}$ atau $1438 \mathrm{M}$.

\section{Batu relief}

Batu relief yang ditemukan di puncak Gunung Lawu pada dasarnya berupa lempengan batu yang pada salah satu ujungnya ditanam di dalam tanah, sehingga batu tersebut pada posisi berdiri. Relief dipahatkan pada salah satu permukaan batu yang relatif 
rata, kedalaman pahatan relief kurang lebih $1 / 2 \mathrm{~cm}$. Motif dari relief tersebut berupa pahatan matahari bersinar, sehingga disebut dengan istilah batu cokro suryo.

\section{Tembikar}

Tembikar adalah salah satu peralatan hidup manusia yang terbuat dari bahan tanah liat. Cara pembuatan benda ini dilakukan dengan membentuk bahan tanah liat sesuai dengan bentuk yang diinginkan. Setelah itu bentuk yang sudah jadi dipanaskan dengan cara dibakar pada temperatur tertentu agar bahan tanah liat tersebut mengeras.

Bentuk tembikar yang ditemukan pada bangunan megalitik di puncak Gunung Lawu antara lain berupa fragmen wadah, fragmen meru (?) dan fragmen kemuncak berhias (?). Pola hias pada benda-benda tembikar tersebut berupa sulur-suluran menyerupai pola hias yang terdapat pada berbagai benda tinggalan arkeologis dari Kerajaan Majapahit.

\section{Keramik}

Keramik merupakan salah satu tinggalan manusia masa lalu yang dapat digunakan sebagai indikator dalam upaya meletakkan situs tersebut ke dalam kerangka waktu Benda ini memiliki sifat yang cenderung tidak mudah rusak atau lapuk, sehingga dapat dengan mudah diamati ciri fisiknya. Ciri-ciri fisik tertentu pada benda ini, misalnya bentuk, pola hias, teknik hias, cara pengerjaan, dan gabungan dari semuanya dapat memberikan referensi tentang perkiraan waktu dan asal pembuatannya. Oleh karena itu, temuan keramik pada lubang uji di situs puncak Gunung Lawu merupakan salah satu temuan penting untuk meletakkan situs ini dalam kerangka waktu.

Temuan keramik di situs puncak Gunung Lawu ditemukan dua buah fragmen bagian badan. Fragmen yang pertama berwarna coklat tua, hiasan dibuat dengan teknik gores, pola hias berupa lengkungan dan dua garis sejajar. Bentuk utuh menunjukkan kecenderungan berupa wadah berukuran be-sar. Glasir hanya tampak pada bagian luar yang tidak tergores, sedangkan pada bagi-an hiasan tidak tampak adanya glasir. Fragmen keramik ini terbuat dari bahan batuan berwarna abu-abu. Fragmen keramik kedua, berwarna putih polos tanpa hiasan. Bentuk utuh menunjukkan kecenderungan berupa wadah berukuran kecil. Glasir merata pada bagian luar berwarna putih susu. Fragmen keramik ini terbuat dari bahan batuan berwarna putih. Analisis terhadap asal dan tahun pembuatan belum dapat dilakukan . 


\section{Arang}

Arang adalah sisa-sisa atau hasil dari suatu aktivitas pembakaran. Arang yang ditemukan di situs Puncak Gunung Lawu tersebar hampir di seluruh permukaan tanah pada semua bangunan. Jenis temuan ini barangkali dapat digunakan sebagai indikator bahwa aktivitas pemujaan pada bangunan berundak di situs puncak Gunung Lawu dilakukan dengan menggunakan unsur api. Selain itu, sisa-sisa pembakaran tersebut dimungkinkan hanya sebagai hasil dari aktivitas profan, misalnya pembuatan api unggun atau masak-memasak.

\section{Pola Sebaran Bangunan Megalitik di Puncak Gunung Lawu}

Konsep baku mengenai kriteria suatu situs megalitik sampai saat ini belum pernah disusun oleh para ahli arkeologi Indonesia. Padahal, konsep tersebut merupakan perangkat yang diperlukan sebagai parameter dalam menentukan karakter suatu situs sebagai situs megalitik. Oleh karena itu, dalam usaha menentukan karakter situs puncak Gunung Lawu akan didasarkan pada hasil analisis terhadap berbagai tinggalan arkeologis yang ada. Selain itu penentuan karakter situs akan didasarkan pula pada latar belakang konsepsi kepercayaan, lokasi penempatan bangunan, dan orientasi bangunan.

Analisis yang telah diuraikan meliputi jenis temuan, jenis bahan baku, lokasi persebaran, dan fungsi. Berbagai uraian terhadap temuan-temuan pada bab sebelumnya, baik temuan permukaan maupun hasil ekskavasi menunjukkan bahwa situs puncak Gunung Lawu adalah situs megalitik. Beberapa unsur pokok yang menunjang pernyataan ini antara lain keberadaan bangunan berundak dengan lima sampai tujuh undakan yang merupakan bangunan tempat pemujaan. Keberadaan lumpang batu, pagar batu, tangga batu, dan batu tegak, semua unsur-unsur tersebut merupakan suatu kesatuan dari apa yang disebut sebagai hasil budaya megalitik, yang pembangunannya diwujudkan sebagai sarana pemujaan terhadap arwah leluhur/nenek moyang. Unsur-unsur tersebut di atas jelas memperlihatkan bahwa situs bangunan berundak di puncak Gunung Lawu sebagai situs megalitik.

Konsepsi kepercayaan yang melatarbelakangi keberadaan bangunan berundak di situs puncak Gunung Lawu adalah konsep kepercayaan terhadap arwah nenek moyang. Masyarakat yang menganut kepercayaan ini beranggapan bahwa ada hubungan timbal balik antara manusia yang masih hidup dengan leluhurnya di alam arwah. Hubungan itu selalu dijaga dengan melakukan upacara-upacara pemujaan. Dalam upacara tersebut diperlukan sarana-sarana yang berfungsi sebagai perwujudan dari arwah nenek moyang. Oleh karena itu, didirikan bangunan-bangunan megalitik yang berfungsi sebagai sarana upacara baik pemujaan maupun penguburan. 
Lokasi penempatan dan orientasi bangunan berundak dapat pula digunakan sebagai petunjuk bahwa tinggalan arkeologis di situs puncak Gunung Lawu adalah hasil budaya megalitik. Asumsi ini didasarkan pada konsepsi kepercayaan manusia pendukung budaya megalitik terhadap gunung. Dalam konsep kepercayaan tersebut, gunung dianggap sebagai simbol dunia arwah atau sebagai tempat tinggal para leluhur (Wales, 1972:34).

\section{E. Pergeseran Pusat Kegiatan Upacara di Situs Megalitik Puncak Gunung Lawu}

Pola Sebaran Bangunan Megalitik di Puncak Gunung Lawu dapat dikatahui berdasarkan lokasi keletakan dan orientasi masing-masing bangunan berundak. Berdasarkan pengamatan terhadap lokasi keletakan sepuluh buah bangunan terlihat adanya persebaran yang tidak merata, sembilan buah bangunan membentuk satu kelompok, sedangkan satu buah lainnya terletak terpisah jauh dari kelompok tersebut. Persebaran bangunan berundak yang berkelompok menunjukkan pola memusat. Hal ini dapat diamati dari bentuk bangunan, letak pintu, dan arah kelerengan. Hal tersebut merupakan petunjuk untuk mengetahui arah orientasi bangunan.

Bangunan berundak Argo Dumilah yang terletak di puncak utama Gunung Lawu, yang bernama puncak Argo Dumilah di kelilingi oleh delapan buah bangunan yang lain. Orientasi delapan buah bangunan di sekelilingnya mengarah ke bangunan berundak Argo Dumilah atau ke arah puncak. Bangunan berundak Argo Dumilah memiliki tiga buah pintu, yaitu menghadap ke timur, utara, dan barat, sedangkan pada sisi selatan bangunan ini berbatasan dengan kawah Lawu lama. Delapan buah bangunan berundak lainnya masing-masing hanya memiliki satu buah pintu, yang terletak membelakangi bangunan berundak Argo Dumilah. Persebaran bangunan tersebut membentuk pola sebaran memusat (lihat tabel 1, peta 02).

Berdasarkan pola sebaran memusat pada bangunan berundak di puncak Gunung Lawu dapat diasumsikan bahwa pada masa bangunan tersebut difungsikan terdapat pembagian fungsi bangunan. Pembagian fungsi bangunan menunjukkan adanya bangunan pusat dan bangunan bukan pusat. Pembagian fungsi bangunan ini barangkali berhubungan pula dengan jenis kegiatan yang dilakukan manusia pada bangunan tersebut, dimana bangunan pusat memiliki fungsi sebagai tempat dilaksanakannya kegiatan utama pada upacara pemujaan. Sedangkan bangunan bukan pusat atau bangunan yang terletak di sekeliling bangunan pusat berlaku sebagai tempat dilaksanakannya kegiatan pelengkap pada upacara pemujaan.

Persebaran dan orientasi bangunan megalitik menunjukkan pola memusat. Bangunan berundak Argo Dumilah yang terletak di puncak utama Gunung Lawu dikelilingi oleh bangunan-bangunan lain dengan orientasi mengarah ke puncak. Pola sebaran tersebut 
menggambarkan adanya pembagian fungsi, yaitu bangunan pusat dan bangunan bukan pusat. Bangunan pusat berfungsi sebagai sarana kegiatan utama dan bangunan bukan pusat berfungsi sebagai sarana kegiatan pelengkap.

\section{F. Penutup}

Bangunan-bangunan megalitik di situs puncak Gunung Lawu sampai saat ini masih digunakan sebagai tempat upacara pemujaan oleh masyarakat di sekitar Gunung Lawu. Hal ini menunjukkan suatu tradisi pemujaan terhadap arwah leluhur yang memanfaatkan bangunan megalitik sebagai sarana upacara pemujaan. Suatu hal yang sangat menarik bahwa pada upacara pemujaan masa kini, pusat kegiatan upacara tidak lagi berada di bangunan Argo Dumilah tetapi di bangunan Argo Dalem Timur. Padahal berdasarkan lokasi sebaran bangunan, Argo Dalem Timur merupakan bangunan yang terletak di posisi bangunan bukan pusat atau bangunan yang terletak di sekeliling bangunan pusat. Hal ini menunjukkan adanya pergeseran pusat kegiatan upacara pemujaan dari bangunan Argo Dumilah ke Argo Dalem Timur.

\section{KEPUSTAKAAN}

Listantyo, Septihandri B. 1992. Tradisi Megalitik di Kawasan Puncak Lawu (Tinjauan Arsitektural Bangunan Berundak), SKRIPSI, Yogyakarta : Fak. Sastra, UGM.

Marsis Sutopo, 1987. Survei Arkeologi Puncak Lawu, ARTEFAK No. 6, Yogyakarta: Himpunan Mahasiswa Arkeologi, hal,13-16.

Priyatno Hadi S., 1993. Penelitian Etno-Arkeologi di Situs Puncak Gunung Lawu, LHPA, Yogyakarta: Balai Arkeologi Yogyakarta.

Simanjuntak. H.Truman, Priyatno Hs., dan M. Hidayat. 1992. Penelitian Arkeologi Situs Baseh, LPA, Yogyakarta: Balai Arkeologi Yogyakarta.

Soejono, R.P. (ed.),1984. Sejarah Nasional Indonesia I, Jakarta: Balai Pustaka.

Sukendar, Haris. 1982. Tinjanan Tentang Berbagai Situs Megalitik di Indonesia, PIA II, Jakarta: Puslitarkenas, hal. 55-68.

Wales, H.G. Quaritch, 1958. The Mountain of God, London: Bernard Quaritch Ltd. 


\section{TABEL 1. PERSEBARAN BANGUNAN BERUNDAK}

DI SITUS PUNCAK GUNUNG LAWU

\begin{tabular}{||l|l|l|l|l||}
\hline No. & \multicolumn{1}{|c|}{$\begin{array}{c}\text { NAMA } \\
\text { BANGUNAN }\end{array}$} & \multicolumn{1}{|c|}{ LOKASI } & \multicolumn{1}{|c||}{ ARAH HADAP } & \multicolumn{1}{|c|}{ ORIENTASI } \\
\hline 01. & Argo Dumilah & Puncak Argo Dumilah & Barat, Utara, Timur & Puncak Argo Dumilah \\
\hline 02. & Argo Dumilah Timur & Lereng Argo Dumilah & Barat $\left(270^{\circ}\right)$ & Puncak Argo Dumilah \\
\hline 03. & Argo Dumilah Utara & Lereng Argo Dumilah & Selatan $\left(180^{\circ}\right)$ & Puncak Argo Dumilah \\
\hline 04. & Argo Dumilah Barat & Lereng Argo Dumilah & Timur $\left(90^{\circ}\right)$ & Puncak Argo Dumilah \\
\hline 05. & Argo Dalem Barat & Lereng Argo Dalem & Barat Daya $\left(240^{\circ}\right)$ & Puncak Argo Dumilah \\
\hline 06. & Argo Dalem Baratlaut & Lereng Argo Dalem & Tenggara $\left(130^{\circ}\right)$ & Puncak Argo Dumilah \\
\hline 07. & Argo Dalem Selatan & Lereng Argo Dalem & Barat Daya $\left(235^{\circ}\right)$ & Puncak Argo Dumilah \\
\hline 08. & Argo Dalem Timur & Lereng Argo Dalem & Barat Daya $\left(230^{\circ}\right)$ & Puncak Argo Dumilah \\
\hline 09. & Sendang Drajat & Lereng Argo Dumilah & Barat Laut $\left(310^{\circ}\right)$ & Puncak Argo Dumilah \\
\hline 10. & Pasar Dieng & Lereng Argo Tiling & Barat Laut $\left(310^{\circ}\right)$ & Puncak Argo Tiling \\
\hline
\end{tabular}

TABEL 2. DAFTAR TEMUAN FRAGMEN TEMBIKAR

HASIL EKSKAVASI DI SITUS PUNCAK G. LAWU

\begin{tabular}{||c|l|l|l|l|l|l|r||}
\hline $\begin{array}{c}\text { No. } \\
\text { Urut }\end{array}$ & \multicolumn{1}{|c|}{$\begin{array}{c}\text { No. } \\
\text { Temuan }\end{array}$} & \multicolumn{1}{|c|}{ Sektor } & Kotak & Spit & \multicolumn{1}{|c|}{ Bagian } & \multicolumn{1}{|c|}{ Bentuk } & JmI. \\
\hline 01. & 8 & Pasar Dieng & LU 1 & $(2)$ & Badan & Periuk & 1 \\
\hline 02. & 9,10 & Pasar Dieng & LU 1 & $(2)$ & Badan hias & Vas Bunga & 2 \\
\hline 03. & $11-14$ & Pasar Dieng & LU 1 & $(2)$ & Badan & Vas Bunga & 3 \\
\hline 04. & $35-41$ & Pasar Dieng & LU 1 & $(2)$ & Badan & Jun & 7 \\
\hline 05. & $49-71$ & Pasar Dieng & LU 2 & $(1)$ & Badan & - & 29 \\
\hline 06. & $110-139$ & Pasar Dieng & LU 2 & $(2)$ & Badan & - & 29 \\
\hline 07. & $140-156$ & Pasar Dieng & LU 2 & $(2)$ & Badan & Periuk & 23 \\
\hline 08. & $6-7$ & Argo Dalem & LU 1 & $(1)$ & Badan & Periuk & 1 \\
\hline 09. & 15 & Argo Dalem & LU 1 & $(2)$ & Tepian & Periuk & 15 \\
\hline 10. & $16-30$ & Argo Dalem & LU 1 & $(2)$ & Leher & Jun & 7 \\
\hline 11. & $35-41$ & Argo Dalem & LU 1 & $(2)$ & Badan & Jun & 1 \\
\hline 12. & 42 & Argo Dalem & LU 2 & $($ P) & Tepian & Pengaron & 6 \\
\hline 13. & $43-48$ & Argo Dalem & LU 2 & $($ P) & Leher & Periuk & 2 \\
\hline 14. & $72-73$ & Argo Dalem & LU 2 & $($ P) & Tepian & Genuk & 1 \\
\hline 15. & 74 & Argo Dalem & LU 2 & $($ P) & Tepian & Periuk & 1 \\
\hline 16. & 75 & Argo Dalem & LU 2 & $($ P) & Dasar & Vas Bunga & 1 \\
\hline 17. & 76 & Argo Dalem & LU 2 & $(1)$ & Tepian & Pengaron & 1 \\
\hline 18. & 77 & Argo Dalem & LU 2 & $(1)$ & Tepian & Piring & 1 \\
\hline 19. & $78-81$ & Argo Dalem & LU 2 & $(1)$ & Tepian & Pengaron & 4 \\
\hline 20. & 82 & Argo Dalem & LU 2 & $(1)$ & Leher & Periuk & 1 \\
\hline 21. & $83-107$ & Argo Dalem & LU 2 & $(1)$ & Badan & Periuk & 25 \\
\hline 22. & $108-109$ & Argo Dalem & LU 2 & $(2)$ & Tepian & Periuk & 2 \\
\hline 23. & $110-139$ & Argo Dalem & LU 2 & $(2)$ & Badan & Periuk & 26 \\
\hline 24. & $140-156$ & Argo Dalem & LU 2 & $(2)$ & Badan & Periuk & 17 \\
\hline 25. & 157 & Argo Dalem & LU 2 & $(3)$ & Hiasan & Meru & 1 \\
\hline 26. & $158-168$ & Argo Dalem & LU 2 & $(3)$ & Badan & Meru & 11 \\
\hline
\end{tabular}


TABEL 3. DAFTAR TEMUAN FRAGMEN TEMBIKAR HASIL SURVEI DI SITUS PUNCAK G. LAWU

\begin{tabular}{||c|c|l|c|l|l|c||}
\hline No. & $\begin{array}{c}\text { No. } \\
\text { Temuan }\end{array}$ & Bangunan & Undakan & \multicolumn{1}{|c||}{ Bagian } & Bentuk & Jml \\
\hline \hline 01. & 1 & Argo Dalem & 3 & Tepian & Meru & 1 \\
\hline 02. & 2 & Argo Dalem & 3 & Tepian & Meru & 1 \\
\hline 03. & 3 & Argo Dalem & 3 & Tepian & Periuk & 1 \\
\hline 04. & 5 & Argo Dalem & 3 & Badan & Periuk & 2 \\
\hline 05. & 169 & Argo Dalem & 3 & Tepian & Meru & 1 \\
\hline 06. & 170 & Argo Dalem & 3 & Tepian & Genuk & 1 \\
\hline 07. & 171 & Argo Dalem & 3 & Tepian & Miniatur & 1 \\
\hline 08. & 172 & Argo Dalem & 3 & Leher & Pasu & 1 \\
\hline 09. & 173 & Argo Dalem & 3 & Tepian & Pengaron & 2 \\
\hline 10. & 174 & Argo Dalem & 3 & Tepian & Genuk & 1 \\
\hline 11. & 175 & Argo Dalem & 3 & Dasar & Piring & \\
\hline 12. & 176 & Argo Dalem & 4 & Tepian & Pengaron & 1 \\
\hline 13. & 177 & Argo Dalem & 4 & Tepian & Genuk & 1 \\
\hline 14. & $178-211$ & Argo Dalem & 4 & Badan & Genuk & 34 \\
\hline 15. & $212-220$ & Argo Dalem & 3 & Badan & Genuk & 9 \\
\hline 16. & $213-258$ & Argo Dalem & 3 & Badan & Genuk & 46 \\
\hline
\end{tabular}




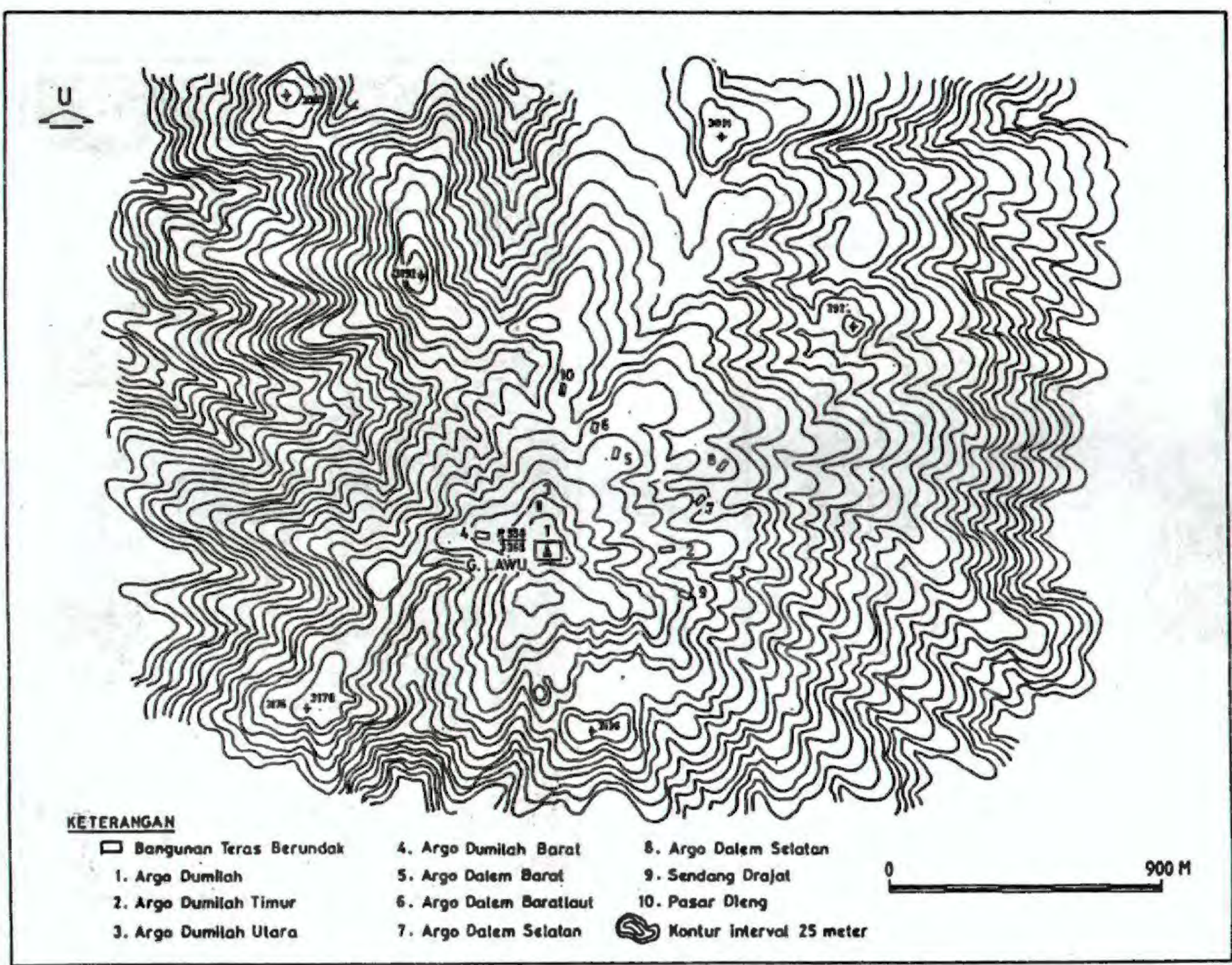

Peta Sebaran Bangunan Megalitik Situs Puncak G. Lawu. 


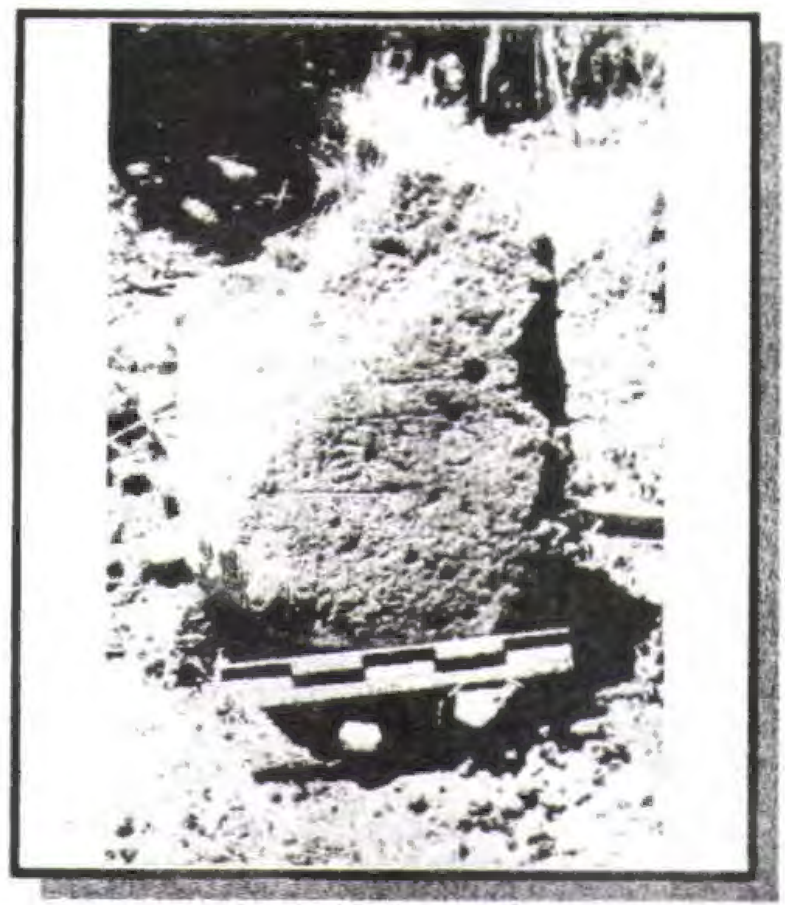

Foto 1. Batu Prasasti Berhuruf Jawa Kuno Di Situs Megalitik Puncak G. Lawu

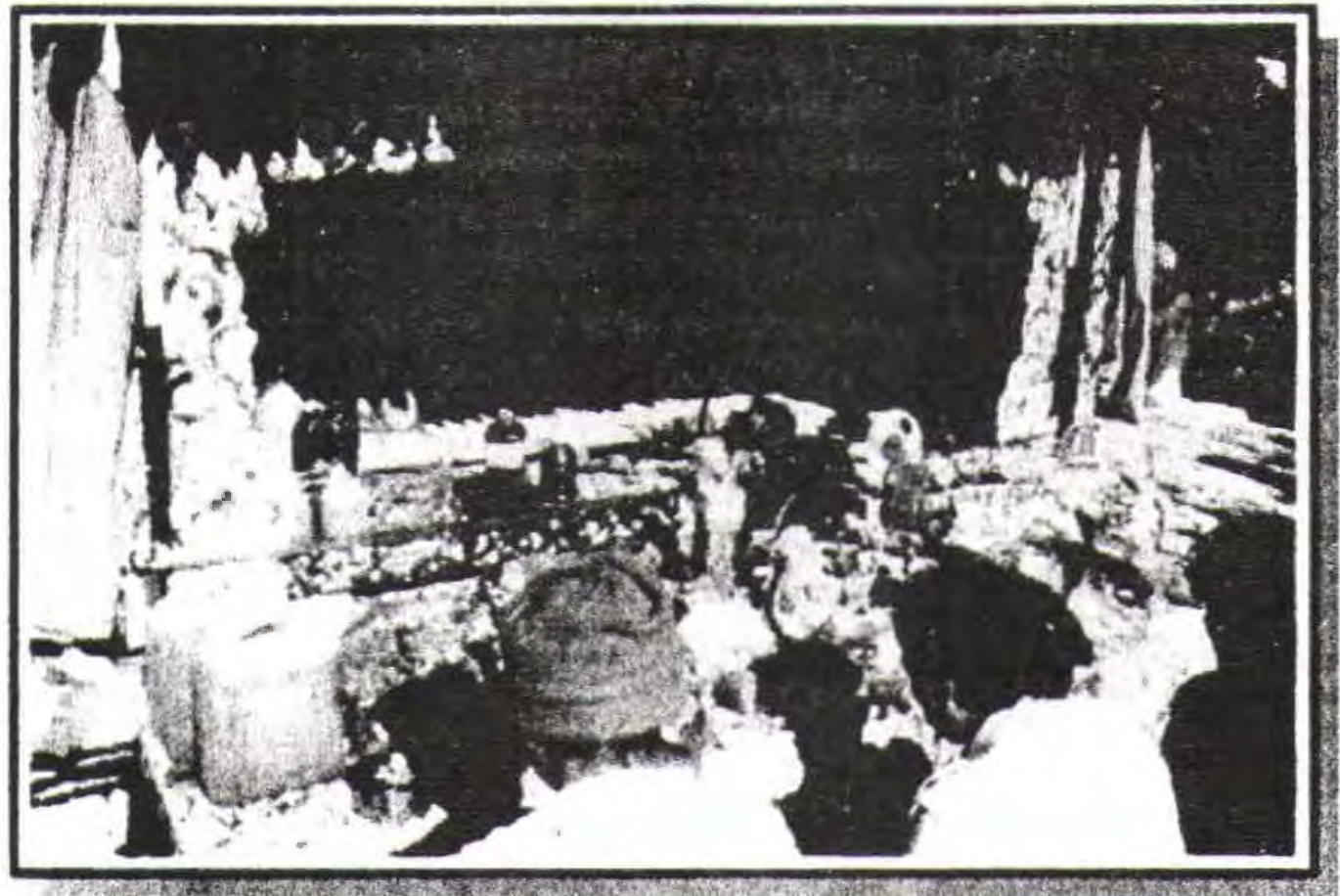

Foto 2. Tempat Pusat Kegiatan Upacara Pemujaan di Lantai 7 Bangunan Berundak Argo Dalem Timur Di Situs Megalitik Puncak G. Lawu 